\title{
Paneth cells: the hub for sensing and regulating intestinal flora
}

\author{
Zheng Zhang ${ }^{1} \&$ Zhihua Liu ${ }^{2 *}$ \\ ${ }^{1}$ Department of Gastroenterology, the Affiliated Yixing Hospital of Jiangsu University, Yixing 214200, China; \\ ${ }^{2}$ CAS Key Laboratory of Infection and Immunity, Institute of Biophysics, Chinese Academy of Sciences, Beijing 100101, China
}

Received November 28, 2015; accepted January 10, 2016; published online February 03, 2016

\begin{abstract}
The complex interplay between symbiotic bacteria and host immunity plays a key role in shaping intestinal homeostasis and maintaining host health. Paneth cells, as one of the major producers of antimicrobial peptides in the intestine under steady-state conditions, play a vital role in regulating intestinal flora. Many studies on inflammatory bowel disease (IBD)-associated genes have put Paneth cells at the center of IBD pathogenesis. In this perspective, we focus on mechanistic studies of different cellular processes in Paneth cells that are regulated by various IBD-associated susceptibility genes, and we discuss the hypothesis that Paneth cells function as the central hub for sensing and regulating intestinal flora in the maintenance of intestinal homeostasis.
\end{abstract}

inflammatory bowel disease, Paneth cell, commensal bacteria, intestinal homeostasis

Citation: Zhang, Z., and Liu, Z. (2016). Paneth cells: the hub for sensing and regulating intestinal flora. Sci China Life Sci 59, 463-467. doi: 10.1007/s11427-016-5018-5

\section{INTRODUCTION}

Trillions of bacteria reside in the human intestinal lumen. These bacteria are usually termed as the intestinal flora or microbiota. The microbiota plays important roles in host health by assisting nutrient digestion and absorption, educating the immune system, regulating metabolism, and fending off intestinal pathogens. Microbial imbalance, known as dysbiosis, has been linked to the development of a wide range of disorders, including metabolic syndromes, autism spectrum disorders, inflammatory bowel disease (IBD), and so on. Therefore, it is important to understand how the intestinal microbiota is established after birth and dynamically regulated throughout life. The intestinal microbiota and mucosal immunity constantly interact and reciprocally shape each other to achieve a steady state which is referred to as intestinal homeostasis. IBD, one of the clinical manifestations of disrupted intestinal homeostasis, has been widely studied to understand the important players in

*Corresponding author (email: zhihualiu@ibp.ac.cn) maintaining intestinal homeostasis.

\section{IBD OVERVIEW}

IBD includes two main forms: Crohn's disease (CD) and ulcerative colitis (UC). IBD is generally thought to arise from inappropriate and sustained responses of host immunity to intestinal microbiota. IBD is a complex disease influenced by both environmental and genetic factors. Genome-wide association studies (GWAS) have identified over 100 distinct loci that confer risk of or protection against developing IBD (Anderson et al., 2011; Franke et al., 2010; Huttenhower et al., 2014; Liu et al., 2015). Mechanistic studies on these associated genes have revealed complex interplay between intestinal microbiota and mucosal immunity. When the interplay goes awry, the host is at risk of intestinal infection or inflammation. For example, a delicate balance between inflammatory Th17 cells and regulatory Treg cells is critical for intestinal homeostasis. Interestingly, among the commensal bacteria, segmented filamentous bacteria (SFB) induce Th17 cell differentiation 
while Clostridia induce the differentiation of colonic Treg cells (Atarashi et al., 2011; Ivanov et al., 2009). Dysbiosis in intestinal flora may tilt the balance between intestinal Th17 and Treg cells, and conversely, the imbalance of intestinal Th17 and Treg cells may set the stage for intestinal dysbiosis.

\section{RECIPROCAL INTERACTION BETWEEN PANETH CELLS AND MICROBES}

Strikingly, a number of studies on IBD-associated genes have since converged on Paneth cells. Paneth cells, a group of secretory cells located at the bottom of small intestinal crypts, secrete a range of anti-microbial peptides (AMPs) into the intestinal lumen (Bevins and Salzman, 2011; Clevers and Bevins, 2013). This perspective focuses on the crosstalk between Paneth cells and intestinal micriobiota and implication in IBD. More comprehensive views on Paneth cells are covered in several review articles (Bevins and Salzman, 2011; Clevers and Bevins, 2013). In-depth mechanistic studies also reveal a complex interplay between Paneth cells and intestinal flora, in which Paneth cells play a critical role in sensing and regulating intestinal flora (Furusawa et al., 2014; Lupp et al., 2012). The AMPs secreted by Paneth cells include cryptdin, Reg3 $\gamma$, lysozyme and so on (Bevins and Salzman, 2011; Clevers and Bevins, 2013). Cryptdin suppresses pathogenic microbes and neutralizes a range of bacterial toxins (Kudryashova et al., 2014). Reg3 $\gamma$ specifically kills Gram-positive bacteria, suggesting that each AMP has its own antimicrobial spectrum. AMPs from Paneth cells are essential for controlling intestinal Listeria monocytogenes infection (Kaser et al., 2008; Kobayashi et al., 2005). Depleting Paneth cells in mice results in a compromised intestinal barrier and enhanced translocation and dissemination of pathogens (Vaishnava et al., 2008).

Reciprocally, intestinal microbes regulate synthesis and secretion of AMPs. AMPs in Paneth cells are stored in dense core vesicles (DCVs) before being secreted into the intestinal lumen. Studies in the 1970s showed that DCVs in Paneth cells from germ-free mice are smaller in size and greater in number (Satoh, 1988). Microbial colonization greatly stimulates DCV secretion in germ-free mice (Satoh, 1988). A study by Ayabe shows that secretion in Paneth cells depends on the presence of bacteria or their ligands (Ayabe et al., 2000). Aside from AMP secretion, the production of $\operatorname{Reg} 3 \gamma$ critically depends on the presence of commensal bacteria. In fact, $\operatorname{Reg} 3 \gamma$ is one of the most upregulated genes in the intestine when germ-free mice are colonized with commensal bacteria (Cash et al., 2006). Both events, bacteria-stimulated secretion and Reg3 $\gamma$ induction, depend on the expression of toll-like receptors (TLRs) and their downstream adaptor protein Myd88 in Paneth cells.
The precise control of AMP synthesis or secretion depends on host factors, and faulty regulation leads to increased risk of intestinal inflammation, exemplified by point mutations in two IBD-associated genes, TCF4 (transcription factor 4) and KCNN4 (potassium intermediate/small conductance calcium-activated channel, subfamily N, member 4) (Simms et al., 2010; Wehkamp et al., 2007). TCF4 encodes a transcription factor that regulates the transcription of AMPs in Paneth cells, while KCNN4 encodes a calcium-activated potassium channel involved in DCV exocytosis.

\section{THE CELLULAR PROCESSES MODULATED BY COMMENSAL BACTERIA IN PANETH CELLS}

Two different pathways are utilized in Paneth cells for sensing microbes: TLR-Myd88 and nucleotide-binding oligomerization domain-containing protein 2 (Nod2). Activation of the TLR-Myd88 pathway is required for upregulation of Reg $3 \gamma$ upon microbial colonization and DCV exocytosis. However, the role of Nod2 in Paneth cells has been more elusive. Nod2 is a cytosolic bacterial sensor that induces cytokine and antimicrobial peptide gene expression in response to the bacterial peptidoglycan muramyl dipeptide (MDP). Mutations in the gene encoding Nod2 are most commonly associated with increased risk of CD (Hugot et al., 2001; Ogura et al., 2001). The three major NOD2 mutations that are associated with $\mathrm{CD}$ abolish or reduce the ability to sense bacterial products (Billmann-Born et al., 2011; Girardin et al., 2003; Inohara et al., 2003; Li et al., 2004; Netea et al., 2005), suggesting that loss of function of Nod2 contributes to the pathogenesis of $\mathrm{CD}$. Our understanding of the function of Nod2 in mucosal immunity is largely based on studies in $\mathrm{Nod}^{-1-}$ mice. Kobayashi observed a marked reduction in production of a few members of the cryptdin family in Nod $2^{-1-}$ Paneth cells; however, later studies suggest that genetic background may have affected the original observation (Kobayashi et al., 2005; Shanahan et al., 2014). Nod $2^{-1-}$ Paneth cells display less antimicrobial activity in vitro in response to MDP. Nod $2^{-1-}$ mice display altered composition of commensal bacteria, and increased susceptibility to enteric infection and piroxicam-induced ileitis (Kobayashi et al., 2005; Petnicki-Ocwieja et al., 2009; Ramanan et al., 2014). Despite such progress, the cellular and molecular mechanisms underlying the intestinal abnormalities in $N o d 2^{-1-}$ mice remain to be further investigated. A recent study has shown that sensing of microbes by Nod2 directs lysozyme sorting in Paneth cells (Zhang et al., 2015). In Paneth cells of germ-free mice or $N o d 2^{-1-}$ mice, newly synthesized lysozyme is targeted to lysosomes for degradation.

DCV-targeted cargos, like other proteins in constitutive secretory pathways, are synthesized in the endoplasmic re- 
ticulum (ER) and processed in the Golgi. It is largely unknown how DCV cargos are selectively sorted and transported to DCVs after exiting the Golgi. Neurons and endocrine cells, such as chromaffin cells in adrenal glands and $\beta$-cells in pancreatic islets, employ DCV-mediated exocytosis to release a wide range of cargos in response to different physiological conditions. Two complementary mechanisms have been proposed for DCV cargo sorting: (i) sorting by entry, and (ii) sorting by retention (Kim et al., 2006). Physical aggregation of cargos, either alone or together with chromogranins, is important for their sorting and retention within DCVs (Kim et al., 2006). However, apart from physical aggregation, little is understood about how DCV cargos are retained within DCVs while factors not destined for DCVs are directed to the endosomal/lysosomal route during DCV maturation. An important insight comes from a study in Caenorhabditis elegans showing that loss of Rab2a function leads to specific lysosomal degradation of a neuropeptide that is normally located in DCVs (Sumakovic et al., 2009). However, the existence of such a mechanism in mammalian cells has not been demonstrated.

Lysozyme, but not other AMPs, is selectively depleted from DCVs in Lrrk2 $2^{-1-}$ Paneth cells (Zhang et al., 2015). $L R R K 2$, originally identified as a gene most mutated in autosomal dominant familial Parkinson's disease (Paisan-Ruiz et al., 2004; Zimprich et al., 2004), encodes a major susceptibility gene for CD (Anderson et al., 2011; Barrett et al., 2008; Franke et al., 2010; Paisan-Ruiz et al., 2004; Zimprich et al., 2004). LRRK2 encodes a 2,527-amino acid cytosolic protein kinase with several functional domains, including leucine-rich repeats (LRRs), a ROC domain, a COR domain, a Ser/Thr kinase domain and a WD40 repeat domain. LRRK2 is specifically expressed in Paneth cells in the intestinal epithelium and a yeast two-hybrid screen identified Rab2a as an interaction partner of LRRK2. LRRK2 deficiency leads to a failure of Rab2a recruitment on the DCV surface. Lysozyme is mistargeted for lysosomal degradation upon depletion of LRRK2 or Rab2a in Paneth cells. Thus, Paneth cells rely on the LRRK2-Rab2a axis in controlling specific cargo sorting in DCVs.

Furthermore, Nod2-dependent commensal bacteria sensing is required for LRRK2- and Rab2a-mediated lysozyme sorting. In regular specific pathogen-free (SPF) mice, Nod2 localizes to DCVs in Paneth cells. In the absence of commensals, Nod2 no longer localizes to DCVs, and LRRK2 and Rab2a also fail to localize to DCVs. Microbial colonization or MDP alone restores DCV localization of Nod2, recruitment of LRRK2 and Rab2a to DCVs, and lysozyme sorting in Paneth cells. Biochemical studies show that Nod2 physically interacts with LRRK2, suggesting a scenario in which Nod2 recruits LRRK2, and subsequently Rab2a, onto DCVs. Thus, Paneth cells rely on Nod2 to sense intestinal microbes and thereby to direct lysozyme sorting.

\section{ER STRESS AND AUTOPHAGY IN PANETH CELLS}

Aside from directly controlling AMP synthesis, sorting, and secretion, IBD-associated genes are involved in other cellular processes, such as the unfolded-protein response (UPR) and autophagy, which are also essential for normal function of Paneth cells. Depletion of the UPR transcription factor Xbpl (X-box binding protein-1) in mouse intestinal epithelium results in exacerbated ER stress and abolition of bactericidal factors in Paneth cells, which causes spontaneous enteritis (Kaser et al., 2008). Defective autophagy in Paneth cells also results in failure of AMP secretion. Impaired Paneth cell function was observed in $\mathrm{CD}$ patients who were homozygous for a highly prevalent risk allele of $A T G 16 L 1$, which encodes the autophagy related 16-like 1 protein, and in mice carrying a hypomorphic variant of Atg16ll $\left(\right.$ Atg 16L1 ${ }^{\mathrm{HM}}$ ) (Cadwell et al., 2008; Cadwell et al., 2010). Persistent norovirus infection abolishes lysozyme secretion in $\operatorname{Atg} 16 L 1^{\mathrm{HM}}$ mice, suggesting that autophagy in Paneth cells is required for stress responses. Indeed, defective autophagy also exacerbates enteritis in mice with Xbp1 deleted in intestinal epithelium (Adolph et al., 2013). Collectively, IBD-associated genes are implicated in a wide range of cellular processes in Paneth cells, highlighting the vital role of Paneth cells in intestinal homeostasis (Figure 1).

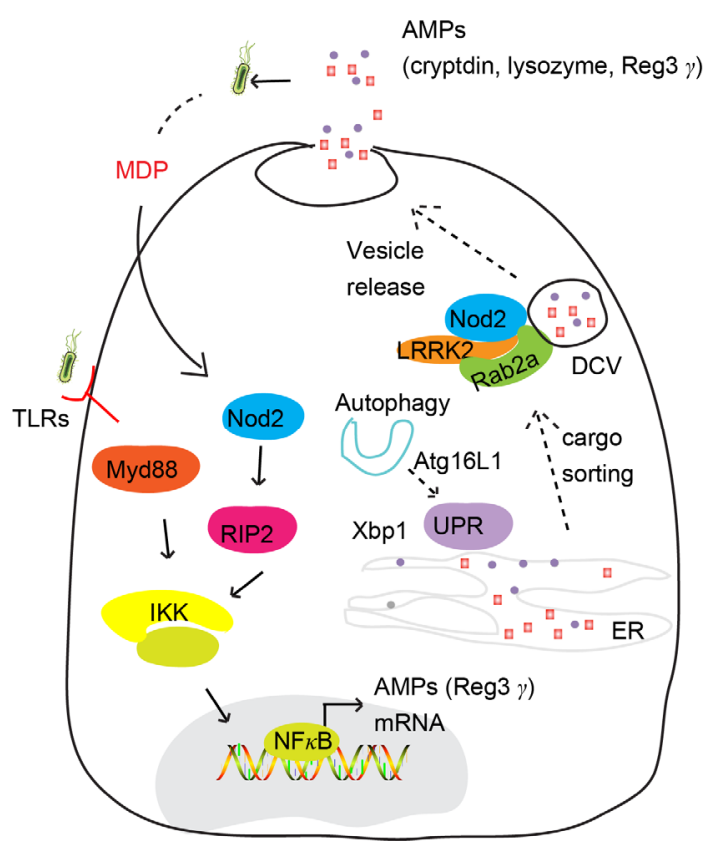

Figure 1 A summary diagram of the cellular processes in Paneth cells which have been implicated in the pathogenesis of IBD. TLRs and Nod2 sense extracellular and intracellular bacterial ligands respectively and activate $\mathrm{NF}-\kappa \mathrm{B}$ via downstream signaling pathways to induce the transcription of genes encoding AMPs. AMP peptides are synthesized in the endoplasmic reticulum (ER). Xbp1 and Atg16L1, regulators of UPR and autophagy respectively, play an essential role in mitigating ER stress. Nod2, LRRK2 and Rab2a orchestrate the selective sorting of lysozyme in DCVs, before the final exocytosis step once DCVs reach the plasma membrane of Paneth cells. AMPs in the intestinal lumen regulate the composition of the gut microbiota. Solid arrows represent signal transduction pathways, while dashed arrows represent cellular processes. 


\section{CONCLUSION}

Currently we are still only beginning to understand the complex interplay between Paneth cells and commensal bacteria. Many of the key interactions remain unknown. For example, besides UPR, autophagy and DCV cargo sorting, are there other cellular processes that are critical for Paneth cell function and involved in IBD pathogenesis? Do commensal bacteria regulate cellular processes other than gene transcription and cargo sorting? What is the physiological function of individual AMPs in regulating the microbiota?

In brief, studies on IBD-associated genes have yielded important insights into the role of Paneth cells in maintaining intestinal homeostasis. While secreting large amounts of AMPs to regulate commensals and kill pathogens, Paneth cells are at the same time subject to regulation by the intestinal flora. Failure of Paneth cells to sense microbes or produce AMPs puts the host at risk of intestinal infection and inflammation. We propose that Paneth cells act as a hub for sensing intestinal microbes and regulating the microbiota. Deciphering more of the interplay between commensals and Paneth cells will shed light on the symbiosis between the host and intestinal microbiota.

Compliance and ethics The author(s) declare that they have no conflict of interest.

Adolph, T.E., Tomczak, M.F., Niederreiter, L., Ko, H.J., Bock, J., Martinez-Naves, E., Glickman, J.N., Tschurtschenthaler, M., Hartwig, J., Hosomi, S., Flak, M.B., Cusick, J.L., Kohno, K., Iwawaki, T., Billmann-Born, S., Raine, T., Bharti, R., Lucius, R., Kweon, M.N., Marciniak, S.J., Choi, A., Hagen, S.J., Schreiber, S., Rosenstiel, P., Kaser, A., and Blumberg, R.S. (2013). Paneth cells as a site of origin for intestinal inflammation. Nature 503, 272-276.

Anderson, C.A., Boucher, G., Lees, C.W., Franke, A., D’Amato, M., Taylor, K.D., Lee, J.C., Goyette, P., Imielinski, M., Latiano, A., Lagace, C., Scott, R., Amininejad, L., Bumpstead, S., Baidoo, L., Baldassano, R.N., Barclay, M., Bayless, T.M., Brand, S., Buning, C., Colombel, J.F., Denson, L.A., De Vos, M., Dubinsky, M., Edwards, C., Ellinghaus, D., Fehrmann, R.S., Floyd, J.A., Florin, T., Franchimont, D., Franke, L., Georges, M., Glas, J., Glazer, N.L., Guthery, S.L., Haritunians, T., Hayward, N.K., Hugot, J.P., Jobin, G., Laukens, D., Lawrance, I., Lemann, M., Levine, A., Libioulle, C., Louis, E., McGovern, D.P., Milla, M., Montgomery, G.W., Morley, K.I., Mowat, C., Ng, A., Newman, W., Ophoff, R.A., Papi, L., Palmieri, O., Peyrin-Biroulet, L., Panes, J., Phillips, A., Prescott, N.J., Proctor, D.D., Roberts, R., Russell, R., Rutgeerts, P., Sanderson, J., Sans, M., Schumm, P., Seibold, F., Sharma, Y., Simms, L.A., Seielstad, M., Steinhart, A.H., Targan, S.R., van den Berg, L.H., Vatn, M., Verspaget, H., Walters, T., Wijmenga, C., Wilson, D.C., Westra, H.J., Xavier, R.J., Zhao, Z.Z., Ponsioen, C.Y., Andersen, V., Torkvist, L., Gazouli, M., Anagnou, N.P., Karlsen, T.H., Kupcinskas, L., Sventoraityte, J., Mansfield, J.C., Kugathasan, S., Silverberg, M.S., Halfvarson, J., Rotter, J.I., Mathew, C.G., Griffiths, A.M., Gearry, R., Ahmad, T., Brant, S.R., Chamaillard, M., Satsangi, J., Cho, J.H., Schreiber, S., Daly, M.J., Barrett, J.C., Parkes, M., Annese, V., Hakonarson, H., Radford-Smith, G., Duerr, R.H., Vermeire, S., Weersma, R.K., and Rioux, J.D. (2011). Meta-analysis identifies 29 additional ulcerative colitis risk loci, increasing the number of confirmed associations to 47 . Nat Genet 43, 246-252.

Atarashi, K., Tanoue, T., Shima, T., Imaoka, A., Kuwahara, T., Momose,
Y., Cheng, G., Yamasaki, S., Saito, T., Ohba, Y., Taniguchi, T., Takeda, K., Hori, S., Ivanov, II, Umesaki, Y., Itoh, K., and Honda, K. (2011). Induction of colonic regulatory $\mathrm{T}$ cells by indigenous Clostridium species. Science 331, 337-341.

Ayabe, T., Satchell, D.P., Wilson, C.L., Parks, W.C., Selsted, M.E., and Ouellette, A.J. (2000). Secretion of microbicidal alpha-defensins by intestinal Paneth cells in response to bacteria. Nat Immunol 1, 113-118.

Barrett, J.C., Hansoul, S., Nicolae, D.L., Cho, J.H., Duerr, R.H., Rioux, J.D., Brant, S.R., Silverberg, M.S., Taylor, K.D., Barmada, M.M., Bitton, A., Dassopoulos, T., Datta, L.W., Green, T., Griffiths, A.M., Kistner, E.O., Murtha, M.T., Regueiro, M.D., Rotter, J.I., Schumm, L.P., Steinhart, A.H., Targan, S.R., Xavier, R.J., Libioulle, C., Sandor, C., Lathrop, M., Belaiche, J., Dewit, O., Gut, I., Heath, S., Laukens, D., Mni, M., Rutgeerts, P., Van Gossum, A., Zelenika, D., Franchimont, D., Hugot, J.P., de Vos, M., Vermeire, S., Louis, E., Cardon, L.R., Anderson, C.A., Drummond, H., Nimmo, E., Ahmad, T., Prescott, N.J., Onnie, C.M., Fisher, S.A., Marchini, J., Ghori, J., Bumpstead, S., Gwilliam, R., Tremelling, M., Deloukas, P., Mansfield, J., Jewell, D., Satsangi, J., Mathew, C.G., Parkes, M., Georges, M., and Daly, M.J. (2008). Genome-wide association defines more than 30 distinct susceptibility loci for Crohn's disease. Nat Genet 40, 955-962.

Bevins, C.L., and Salzman, N.H. (2011). Paneth cells, antimicrobial peptides and maintenance of intestinal homeostasis. Nat Rev Microbiol 9, 356-368.

Billmann-Born, S., Till, A., Arlt, A., Lipinski, S., Sina, C., Latiano, A., Annese, V., Hasler, R., Kerick, M., Manke, T., Seegert, D., Hanidu, A., Schafer, H., van Heel, D., Li, J., Schreiber, S., and Rosenstiel, P. (2011). Genome-wide expression profiling identifies an impairment of negative feedback signals in the Crohn's disease-associated NOD2 variant L1007fsinsC. J Immunol 186, 4027-4038.

Cadwell, K., Liu, J.Y., Brown, S.L., Miyoshi, H., Loh, J., Lennerz, J.K., Kishi, C., Kc, W., Carrero, J.A., Hunt, S., Stone, C.D., Brunt, E.M., Xavier, R.J., Sleckman, B.P., Li, E., Mizushima, N., Stappenbeck, T.S., and Virgin, H.W.4th. (2008). A key role for autophagy and the autophagy gene Atg16l1 in mouse and human intestinal Paneth cells. Nature 456, 259-263.

Cadwell, K., Patel, K.K., Maloney, N.S., Liu, T.C., Ng, A.C., Storer, C.E., Head, R.D., Xavier, R., Stappenbeck, T.S., and Virgin, H.W. (2010). Virus-plus-susceptibility gene interaction determines Crohn's disease gene Atg16L1 phenotypes in intestine. Cell 141, 1135-1145.

Cash, H.L., Whitham, C.V., Behrendt, C.L., and Hooper, L.V. (2006). Symbiotic bacteria direct expression of an intestinal bactericidal lectin. Science 313, 1126-1130.

Clevers, H.C., and Bevins, C.L. (2013). Paneth cells: maestros of the small intestinal crypts. Annu Rev Physiol 75, 289-311.

Franke, A., McGovern, D.P., Barrett, J.C., Wang, K., Radford-Smith, G.L., Ahmad, T., Lees, C.W., Balschun, T., Lee, J., Roberts, R., Anderson, C.A., Bis, J.C., Bumpstead, S., Ellinghaus, D., Festen, E.M., Georges, M., Green, T., Haritunians, T., Jostins, L., Latiano, A., Mathew, C.G., Montgomery, G.W., Prescott, N.J., Raychaudhuri, S., Rotter, J.I., Schumm, P., Sharma, Y., Simms, L.A., Taylor, K.D., Whiteman, D., Wijmenga, C., Baldassano, R.N., Barclay, M., Bayless, T.M., Brand, S., Buning, C., Cohen, A., Colombel, J.F., Cottone, M., Stronati, L., Denson, T., De Vos, M., D’Inca, R., Dubinsky, M., Edwards, C., Florin, T., Franchimont, D., Gearry, R., Glas, J., Van Gossum, A., Guthery, S.L., Halfvarson, J., Verspaget, H.W., Hugot, J.P., Karban, A., Laukens, D., Lawrance, I., Lemann, M., Levine, A., Libioulle, C., Louis, E., Mowat, C., Newman, W., Panes, J., Phillips, A., Proctor, D.D., Regueiro, M., Russell, R., Rutgeerts, P., Sanderson, J., Sans, M., Seibold, F., Steinhart, A.H., Stokkers, P.C., Torkvist, L., Kullak-Ublick, G., Wilson, D., Walters, T., Targan, S.R., Brant, S.R., Rioux, J.D., D'Amato, M., Weersma, R.K., Kugathasan, S., Griffiths, A.M., Mansfield, J.C., Vermeire, S., Duerr, R.H., Silverberg, M.S., Satsangi, J., Schreiber, S., Cho, J.H., Annese, V., Hakonarson, H., Daly, M.J., and Parkes, M. (2010). Genome-wide meta-analysis increases to 71 the number of confirmed Crohn's disease susceptibility loci. Nat Genet 42, 1118-1125.

Furusawa, Y., Obata, Y., and Hase, K. (2015). Commensal microbiota regulates $\mathrm{T}$ cell fate decision in the gut. Semin Immunopathol 37, 
$17-25$.

Girardin, S.E., Boneca, I.G., Viala, J., Chamaillard, M., Labigne, A., Thomas, G., Philpott, D.J., and Sansonetti, P.J. (2003). Nod2 is a general sensor of peptidoglycan through muramyl dipeptide (MDP) detection. J Biol Chem 278, 8869-8872.

Hugot, J.P., Chamaillard, M., Zouali, H., Lesage, S., Cezard, J.P., Belaiche, J., Almer, S., Tysk, C., O’Morain, C.A., Gassull, M., Binder, V., Finkel, Y., Cortot, A., Modigliani, R., Laurent-Puig, P., Gower-Rousseau, C., Macry, J., Colombel, J.F., Sahbatou, M., and Thomas, G. (2001). Association of NOD2 leucine-rich repeat variants with susceptibility to Crohn's disease. Nature 411, 599-603.

Huttenhower, C., Kostic, A.D., and Xavier, R.J. (2014). Inflammatory bowel disease as a model for translating the microbiome. Immunity 40 , 843-854.

Inohara, N., Ogura, Y., Fontalba, A., Gutierrez, O., Pons, F., Crespo, J., Fukase, K., Inamura, S., Kusumoto, S., Hashimoto, M., Foster, S.J., Moran, A.P., Fernandez-Luna, J.L., and Nunez, G. (2003). Host recognition of bacterial muramyl dipeptide mediated through NOD2. Implications for Crohn's disease. J Biol Chem 278, 5509-5512.

Ivanov, II, Atarashi, K., Manel, N., Brodie, E.L., Shima, T., Karaoz, U., Wei, D., Goldfarb, K.C., Santee, C.A., Lynch, S.V., Tanoue, T., Imaoka, A., Itoh, K., Takeda, K., Umesaki, Y., Honda, K., and Littman, D.R. (2009). Induction of intestinal Th17 cells by segmented filamentous bacteria. Cell 139, 485-498.

Kaser, A., Lee, A.H., Franke, A., Glickman, J.N., Zeissig, S., Tilg, H., Nieuwenhuis, E.E., Higgins, D.E., Schreiber, S., Glimcher, L.H., and Blumberg, R.S. (2008). XBP1 links ER stress to intestinal inflammation and confers genetic risk for human inflammatory bowel disease. Cell $134,743-756$.

Kim, T., Gondre-Lewis, M.C., Arnaoutova, I., and Loh, Y.P. (2006). Dense-core secretory granule biogenesis. Physiology 21, 124-133.

Kobayashi, K.S., Chamaillard, M., Ogura, Y., Henegariu, O., Inohara, N., Nunez, G., and Flavell, R.A. (2005). Nod2-dependent regulation of innate and adaptive immunity in the intestinal tract. Science 307, 731-734.

Kudryashova, E., Quintyn, R., Seveau, S., Lu, W., Wysocki, V.H., and Kudryashov, D.S. (2014). Human defensins facilitate local unfolding of thermodynamically unstable regions of bacterial protein toxins. Immunity 41, 709-721.

Li, J., Moran, T., Swanson, E., Julian, C., Harris, J., Bonen, D.K., Hedl, M., Nicolae, D.L., Abraham, C., and Cho, J.H. (2004). Regulation of IL-8 and IL-1beta expression in Crohn's disease associated NOD2/CARD15 mutations. Hum Mol Genet 13, 1715-1725.

Liu, J.Z., van Sommeren, S., Huang, H., Ng, S.C., Alberts, R., Takahashi, A., Ripke, S., Lee, J.C., Jostins, L., Shah, T., Abedian, S., Cheon, J.H., Cho, J., Daryani, N.E., Franke, L., Fuyuno, Y., Hart, A., Juyal, R.C., Juyal, G., Kim, W.H., Morris, A.P., Poustchi, H., Newman, W.G., Midha, V., Orchard, T.R., Vahedi, H., Sood, A., Sung, J.J., Malekzadeh, R., Westra, H.J., Yamazaki, K., Yang, S.K., Barrett, J.C., Franke, A., Alizadeh, B.Z., Parkes, M., B, K.T., Daly, M.J., Kubo, M., Anderson, C.A., and Weersma, R.K. (2015). Association analyses identify 38 susceptibility loci for inflammatory bowel disease and highlight shared genetic risk across populations. Nat Genet 47, 979-986.

Lupp, C., Skipper, M., and Weiss, U. (2012). Gut microbes and health. Nature 489, 219.

Netea, M.G., Ferwerda, G., de Jong, D.J., Werts, C., Boneca, I.G., Jehanno, M., Van Der Meer, J.W., Mengin-Lecreulx, D., Sansonetti, P.J., Philpott, D.J., Dharancy, S., and Girardin, S.E. (2005). The frameshift mutation in Nod2 results in unresponsiveness not only to Nod2- but also Nod1-activating peptidoglycan agonists. J Biol Chem 280, 35859-35867.

Ogura, Y., Bonen, D.K., Inohara, N., Nicolae, D.L., Chen, F.F., Ramos, R., Britton, H., Moran, T., Karaliuskas, R., Duerr, R.H., Achkar, J.P., Brant, S.R., Bayless, T.M., Kirschner, B.S., Hanauer, S.B., Nunez, G., and Cho, J.H. (2001). A frameshift mutation in NOD2 associated with susceptibility to Crohn's disease. Nature 411, 603-606.

Paisan-Ruiz, C., Jain, S., Evans, E.W., Gilks, W.P., Simon, J., van der Brug, M., Lopez de Munain, A., Aparicio, S., Gil, A.M., Khan, N., Johnson, J., Martinez, J.R., Nicholl, D., Carrera, I.M., Pena, A.S., de Silva, R., Lees, A., Marti-Masso, J.F., Perez-Tur, J., Wood, N.W., and Singleton, A.B. (2004). Cloning of the gene containing mutations that cause PARK8-linked Parkinson's disease. Neuron 44, 595-600.

Petnicki-Ocwieja, T., Hrncir, T., Liu, Y.J., Biswas, A., Hudcovic, T., Tlaskalova-Hogenova, H., and Kobayashi, K.S. (2009). Nod2 is required for the regulation of commensal microbiota in the intestine. Proc Natl Acad Sci USA 106, 15813-15818.

Ramanan, D., Tang, M.S., Bowcutt, R., Loke, P., and Cadwell, K. (2014). Bacterial sensor Nod2 prevents inflammation of the small intestine by restricting the expansion of the commensal Bacteroides vulgatus. Immunity 41, 311-324.

Satoh, Y. (1988). Effect of live and heat-killed bacteria on the secretory activity of Paneth cells in germ-free mice. Cell Tissue Res 251, 87-93.

Shanahan, M.T., Carroll, I.M., Grossniklaus, E., White, A., von Furstenberg, R.J., Barner, R., Fodor, A.A., Henning, S.J., Sartor, R.B., and Gulati, A.S. (2014). Mouse Paneth cell antimicrobial function is independent of Nod2. Gut 63, 903-910.

Simms, L.A., Doecke, J.D., Roberts, R.L., Fowler, E.V., Zhao, Z.Z., McGuckin, M.A., Huang, N., Hayward, N.K., Webb, P.M., Whiteman, D.C., Cavanaugh, J.A., McCallum, R., Florin, T.H., Barclay, M.L., Gearry, R.B., Merriman, T.R., Montgomery, G.W., and Radford-Smith, G.L. (2010). KCNN4 gene variant is associated with ileal Crohn's Disease in the Australian and New Zealand population. Am J Gastroenterol 105, 2209-2217.

Sumakovic, M., Hegermann, J., Luo, L., Husson, S.J., Schwarze, K., Olendrowitz, C., Schoofs, L., Richmond, J., and Eimer, S. (2009). UNC-108/RAB-2 and its effector RIC-19 are involved in dense core vesicle maturation in Caenorhabditis elegans. J Cell Biol 186, 897-914.

Vaishnava, S., Behrendt, C.L., Ismail, A.S., Eckmann, L., and Hooper, L.V. (2008). Paneth cells directly sense gut commensals and maintain homeostasis at the intestinal host-microbial interface. Proc Natl Acad Sci USA 105, 20858-20863.

Wehkamp, J., Wang, G., Kubler, I., Nuding, S., Gregorieff, A., Schnabel, A., Kays, R.J., Fellermann, K., Burk, O., Schwab, M., Clevers, H., Bevins, C.L., and Stange, E.F. (2007). The Paneth cell alpha-defensin deficiency of ileal Crohn's disease is linked to Wnt/Tcf-4. J Immunol 179, 3109-3118.

Zhang, Q., Pan, Y., Yan, R., Zeng, B., Wang, H., Zhang, X., Li, W., Wei, H., and Liu, Z. (2015). Commensal bacteria direct selective cargo sorting to promote symbiosis. Nat Immunol 16, 918-926.

Zimprich, A., Biskup, S., Leitner, P., Lichtner, P., Farrer, M., Lincoln, S., Kachergus, J., Hulihan, M., Uitti, R.J., Calne, D.B., Stoessl, A.J., Pfeiffer, R.F., Patenge, N., Carbajal, I.C., Vieregge, P., Asmus, F., Muller-Myhsok, B., Dickson, D.W., Meitinger, T., Strom, T.M., Wszolek, Z.K., and Gasser, T. (2004). Mutations in LRRK2 cause autosomal-dominant parkinsonism with pleomorphic pathology. Neuron 44, 601-607.

Open Access This article is distributed under the terms of the Creative Commons Attribution License which permits any use, distribution, and reproduction in any medium, provided the original author(s) and source are credited. 